$\underline{\text { Original Article }}$

\title{
QUANTITATIVE ANALYSIS OF PAMABROM AND IBUPROFEN IN SYNTHETIC MIXTURE USING $1^{\text {ST ORDER DERIVATIVE SPECTROSCOPY }}$
}

\author{
PINAK PATEL ${ }^{*}$, PRIYANKA VASANI ${ }^{1}$, BINNY MEHTA², KRUNAL DETHOLIA ${ }^{3}$
}

*Department of Pharmaceutical Quality Assurance, Smt. S. M. Shah Pharmacy College, Amsaran, Gujarat 387130, 1,2Department of Pharmaceutical Quality Assurance, Smt. S. M. Shah Pharmacy College, Amsaran, Gujarat 387130, ${ }^{3}$ Department of Pharmaceutics, Smt. S. M. Shah Pharmacy College, Amsaran, Gujarat 387130

Email: pinakqa@gmail.com

Received: 06 Jul 2019, Revised and Accepted: 02 Sep 2019

\section{ABSTRACT}

Objective: The preliminary goal was to develop and validate $1^{\text {st }}$ order derivative spectroscopic method for quantitative analysis of Pamabrom (PAMA) which is a xanthine diuretic and ibuprofen (IBU) which is a non-steroidal anti-inflammatory agent from its synthetic mixture.

Methods: Analytical method was developed on Shimadzu double beam spectrophotometer equipped with UV probe 2.42 as software using methanol as solvent. Quantification of PAMA was carried out at zero cross over point of IBU that is $291 \mathrm{~nm}$ and for IBU, it was achieved at $278 \mathrm{~nm}$ which is zero cross over point of PAMA. Method was validated according to ICH Q2 R1 guidelines.

Results: Method showed a linear response in the range of $2-12 \mu \mathrm{g} / \mathrm{ml}$ of PAMA and $20-120 \mu \mathrm{g} / \mathrm{ml}$ of IBU. Method was found to be accurate with recovery between $99.7-100.9 \%$ for PAMA and 100.3-100.7 \% for IBU. The method was found to be accurate and precise for quantitative analysis of PAMA and IBU.

Conclusion: The developed method was successfully validated as per ICH Q2 R1 guidelines and was successfully applied for quantitative analysis of a synthetic mixture of PAMA and IBU.

Keywords: Pamabrom, Ibuprofen, Derivative spectroscopy, Zero crossover point, Analytical method validation

(C) 2019 The Authors. Published by Innovare Academic Sciences Pvt Ltd. This is an open access article under the CC BY license (http://creativecommons.org/licenses/by/4.0/) DOI: http://dx.doi.org/10.22159/ijpps.2019v11i10.34797

\section{INTRODUCTION}

Pamabrom (PAMA) belongs to the class of xanthene diuretics, which basically contains purine moiety and is approved by US FDA for treatment of menstruation bloating, premenstrual dysphoric disorders, while ibuprofen (IBU) is non-steroidal anti-inflammatory (NSAID's) drug that is propionic acid derivative which is approved by Indian pharmacopoeia (IP), United states pharmacopoeia (USP) and Japanese pharmacopoeia (IP) for management of mild-to-moderate pain associated with dysmenorrhea and arthritis [1-7]. 40-90\% of women of childbearing age complained of primary dysmenorrhea, which is characterized in cyclic pelvic pain during the menstrual period, vomit and headache. NSAIDs were administered to patients because prostaglandins and leukotriene were reported as major factors for dysmenorrhea. Among the all NSAID's, IBU has shown better tolerability which forms the basis of combining PAMA and IBU for treatment of pain associated with renal calculi and dysmenorrhea. PAMA and IBU are officially quantified by HPLC [8]. Several analytical methods are available which can determine IBU and PAMA individually or in combination with another drug [9-26]. Literature review revealed one complex RP-HPLC method for quantitative analysis of PAMA and IBU.

Among different analytical methods, UV spectrophotometric method is perhaps the most quickest and robust method and no UV spectrophotometric method has been reported for estimation of IBU and PAMA in synthetic mixture. More specifically derivative spectroscopy has the advantage to be more specific in comparison to other multicomponent UV spectrophotometric methods.

So by considering the above facts, it was decided to develop and validate $1^{\text {st }}$ order derivative spectrophotometric method for quantitative analysis of IBU and PAMA, as it has less complexity and offers a better economy.

\section{MATERIALS AND METHODS}

\section{Materials}

PAMA was obtained as gratis sample (99.95\% pure) for research purpose from Amoli organics, Vadodara while IBU was obtained as gratis sample from OSAKA pharmaceuticals, Sakrda, Baroda. Methanol (LR grade) was purchase from SD fines.

Instrument and experimental conditions

Spectrophotometric analysis was performed on Shimadzu UV-1800 double beam spectrophotometer having a path length of $1 \mathrm{~cm}$ matched pair of quartz cell. Obtained spectra of PAMA and IBU were derivatized to $1^{\text {st }}$ order using UV probe 2.42 as software at delta $\Lambda$ of $10 \mathrm{~nm}$.

\section{Preparation of master stock solution}

For the method development purpose, $10 \mathrm{mg}$ of PAMA was weighed and diluted to $10 \mathrm{ml}(1000 \mu \mathrm{g} / \mathrm{ml})$ and was further diluted to give final concentration of $100 \mu \mathrm{g} / \mathrm{ml}$. In a similar way, $50 \mathrm{mg}$ of IBU was weighed and diluted to $50 \mathrm{ml}(1000 \mu \mathrm{g} / \mathrm{ml})$ and was further diluted to give the final concentration of $200 \mu \mathrm{g} / \mathrm{ml}$.

\section{Selection of analytical wavelength}

The working standards of PAMA (2-12 $\mu \mathrm{g} / \mathrm{ml})$ and IBU (20-120 $\mu \mathrm{g} / \mathrm{ml}$ ) were prepared in $10 \mathrm{ml}$ volumetric flask using methanol as a solvent. They were scanned in the UV range of 200-400 $\mathrm{nm}$ and D ${ }^{\circ}$ spectra is recorded by UV spectrophotometer. All the $\mathrm{D}^{\circ}$ spectra of PAMA and IBU were transformed into $\mathrm{D}^{1}$ spectra with the help of UV probe 2.42 software. For confirmation of $\mathrm{D}^{1}$ spectra of PAMA and IBU, $\mathrm{D}^{\circ}$ and $\mathrm{D}^{1}$ spectra of the same were overlapped.

Preparation of solutions for analytical method validation

Preparation of solution for linearity and range

To check the linearity of the method, PAMA was prepared in the concentration range of $2-16 \mu \mathrm{g} / \mathrm{ml}$ and IBU was prepared in the range of $20-160 \mu \mathrm{g} / \mathrm{ml}$ from master stock solution in $10 \mathrm{ml}$ volumetric flask. When $\mathrm{D}^{1}$ Absorbance was plotted against concentration, non-linearity was observed above $12 \mu \mathrm{g} / \mathrm{ml}$ for PAMA and above $120 \mu \mathrm{g} / \mathrm{ml}$ for IBU so final range for validation was selected at mixture containing $2-12 \mu \mathrm{g} / \mathrm{ml}$ for PAMA and 20-120 $\mu \mathrm{g} / \mathrm{ml}$ for IBU. All prepared solution was scanned between 200-400 
$\mathrm{nm}$ and all spectra were derivatized to $1^{\text {st }}$ order. $\mathrm{D}^{1}$ absorbance was obtained at selected wavelength and mean $\mathrm{D}^{1}$ absorbance was plotted against concentration.

\section{Intermediate precision (Repeatability)}

To adjudge the repeatability of the analytical method, the solution of linearity studies were analyzed for five-time with same conditions. Mean $\mathrm{D}^{1}$ absorbance was recorded at all concentration for PAMA and IBU and were observed for relative standard deviation.

\section{Method precision}

Method precision was determined by performing intraday and interday precision. The mixture that represents overall range $(2+20$,
$8+80$ and $12+120 \mu \mathrm{g} / \mathrm{ml}$ ) were analyzed on the same day at different time interval for intraday precision. The mixture that represents overall range $(2+20,8+80$ and $12+120 \mu \mathrm{g} / \mathrm{ml})$ were analyzed on different days for interday precision.

\section{Accuracy study}

Accuracy of the analytical method was adjudged by spiking of placebo with standard solution. The mixture containing $100 \mathrm{mg}$ of directly compressible lactose, $2 \mathrm{mg}$ of talc and $2 \mathrm{mg}$ of magnesium stearate was selected as placebo and was spiked at 50, 100 and $150 \%$ of target concentration $(8+80 \mu \mathrm{g} / \mathrm{ml})$ (table 1$)$. Each spiked concentration was analyzed for three times and mean \% recovery was observed at each spiked level.

Table 1: Preparation of solutions for accuracy study

\begin{tabular}{lllll}
\hline $\begin{array}{l}\text { Level of } \\
\text { spiking }\end{array}$ & $\begin{array}{l}\text { Quantity of placebo } \\
(\mathbf{m g})\end{array}$ & $\begin{array}{l}\text { The volume of stock solution } \\
(\mathbf{m l})\end{array}$ & $\begin{array}{l}\text { The volume of diluent taken } \\
(\mathbf{m l})\end{array}$ & $\begin{array}{l}\text { Final concentration } \\
(\boldsymbol{\mu g} / \mathbf{m l})\end{array}$ \\
\hline & & & 10 & PAMA \\
\hline Unspiked & 104 & 0 & 9.6 & - \\
$50 \%$ & 104 & 0.4 & 9.2 & 4 \\
$100 \%$ & 104 & 0.8 & 8.8 & 8 \\
$150 \%$ & 104 & 1.2 & 80 \\
\hline
\end{tabular}

A stock solution was prepared by weighing $5 \mathrm{mg}$ PAMA and $50 \mathrm{mg}$ IBU and was dissolved in $50 \mathrm{ml}$ methanol $(100 \mu \mathrm{g} / \mathrm{ml}$ for PAMA and $1000 \mu \mathrm{g} / \mathrm{ml}$ for IBU respectively)

\section{Solvent stability}

Solvent stability was determined by scanning the same solution prepared in selected solvent (methanol) at 3 different time interval that is at 0 hour, $6 \mathrm{~h}$ and $24 \mathrm{~h}$. The mixture of $12+120 \mu \mathrm{g} / \mathrm{ml}$ solution of PAMA and IBU in methanol were scanned at the selected time interval and characteristics of spectra were compared $\left(\lambda_{\max }\right)$.

\section{Assay}

As the proposed synthetic mixture is having dose of $20 \mathrm{mg}$ of PAMA and $200 \mathrm{mg}$ of IBU, $20 \mathrm{mg}$ of PAMA and $200 \mathrm{mg}$ of IBU was mixed with selected placebo, and diluted appropriately to give a mixture containing $8 \mu \mathrm{g} / \mathrm{ml}$ of PAMA and $80 \mu \mathrm{g} / \mathrm{ml}$ of IBU. This mixture was scanned between $200-400 \mathrm{~nm}$ and was derivatized to $1^{\text {st }}$ order. $\mathrm{D}^{1}$ absorbance was measured at selected wavelengths and was transformed to concentration with help of linear regression equation. This mixture was analyzed for three times and the mean \% assay was drawn.

\section{RESULTS AND DISCUSSION}

\section{Selection of analytical wavelength}

Three different ZCP at $278 \mathrm{~nm}, 316 \mathrm{~nm}$ and $245 \mathrm{~nm}$ was observed in overlain $\mathrm{D}^{1}$ spectra of PAMA (fig. 1). Three different ZCP at $250 \mathrm{~nm}, 261$ $\mathrm{nm}$ and $291 \mathrm{~nm}$ were observed in overlain $\mathrm{D}^{1}$ spectra of IBU (fig. 2). For determination of analytical wavelength $\mathrm{D}^{1}$ spectra of PAMA and IBU were overlapped (fig. 3). While recording $\mathrm{D}^{1}$ absorbance of PAMA at ZCP of IBU, nonlinearity was observed at 250 and $261 \mathrm{~nm}$ while at 291 , the linear response was observed with concentration (fig. 4). In similar way at ZCP of PAMA, linearity was observed only at $278 \mathrm{~nm}$ for IBU (fig. 5). So $291 \mathrm{~nm}$ and $278 \mathrm{~nm}$ was selected as analytical wavelength for quantitative determination of PAMA and IBU respectively.

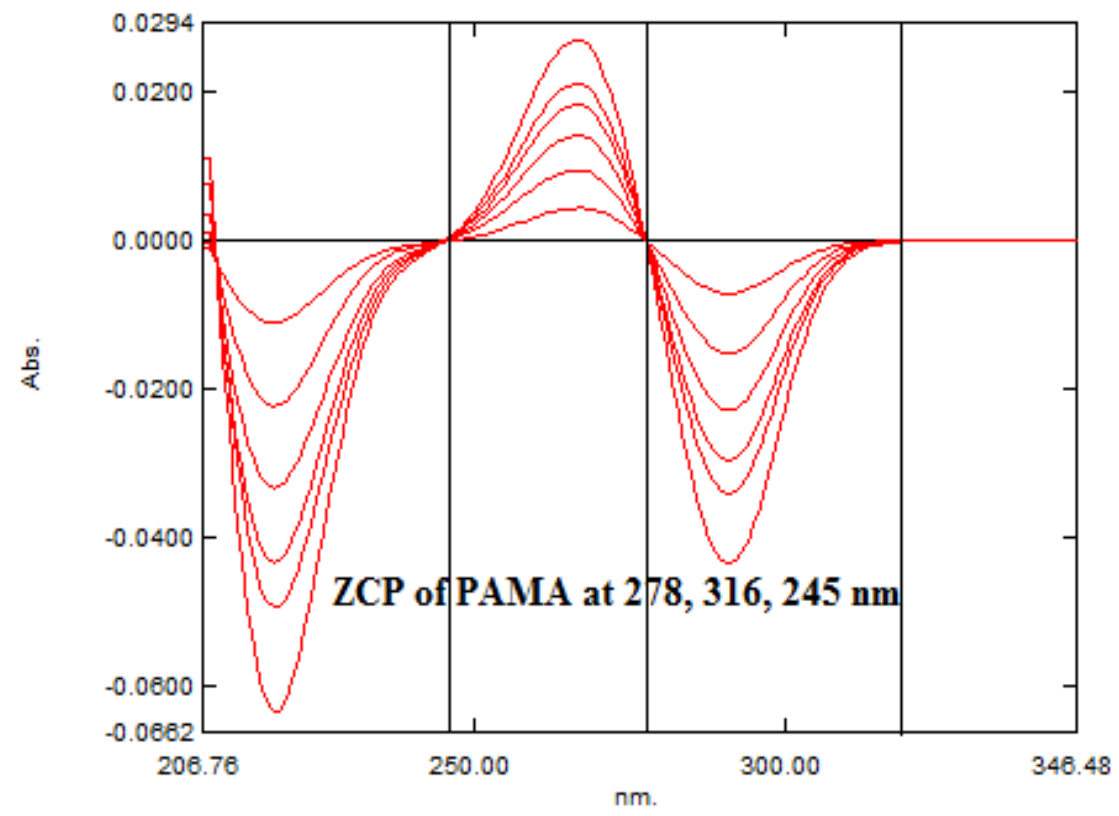

Fig. 1: Zero cross over point of PAMA 


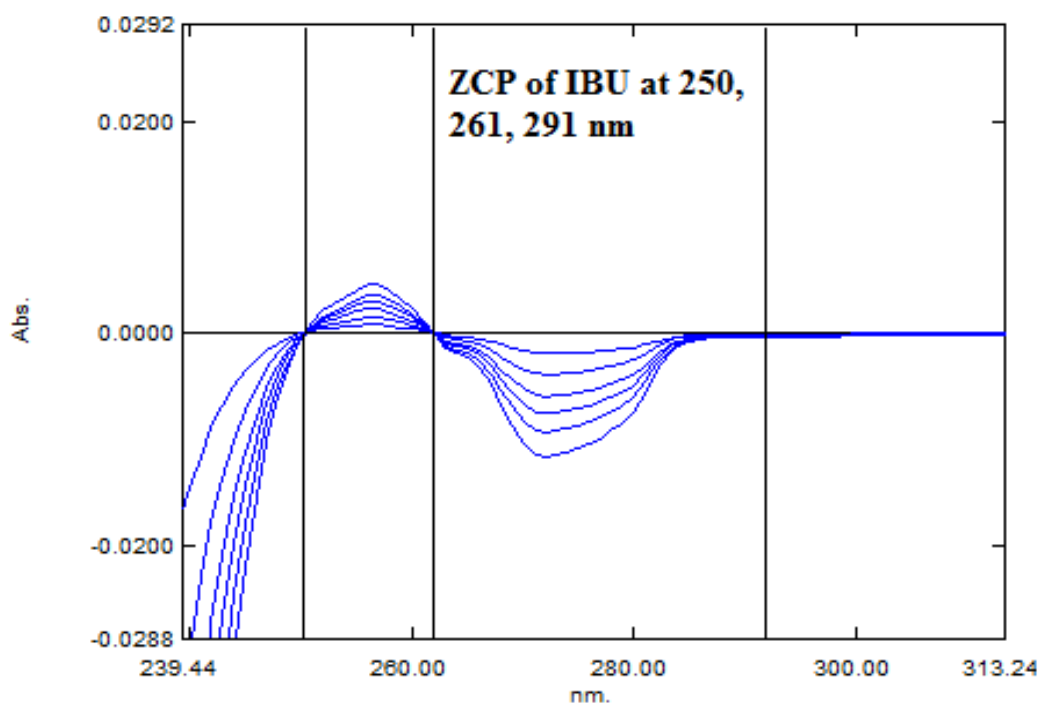

Fig. 2: Zero cross over point of IBU

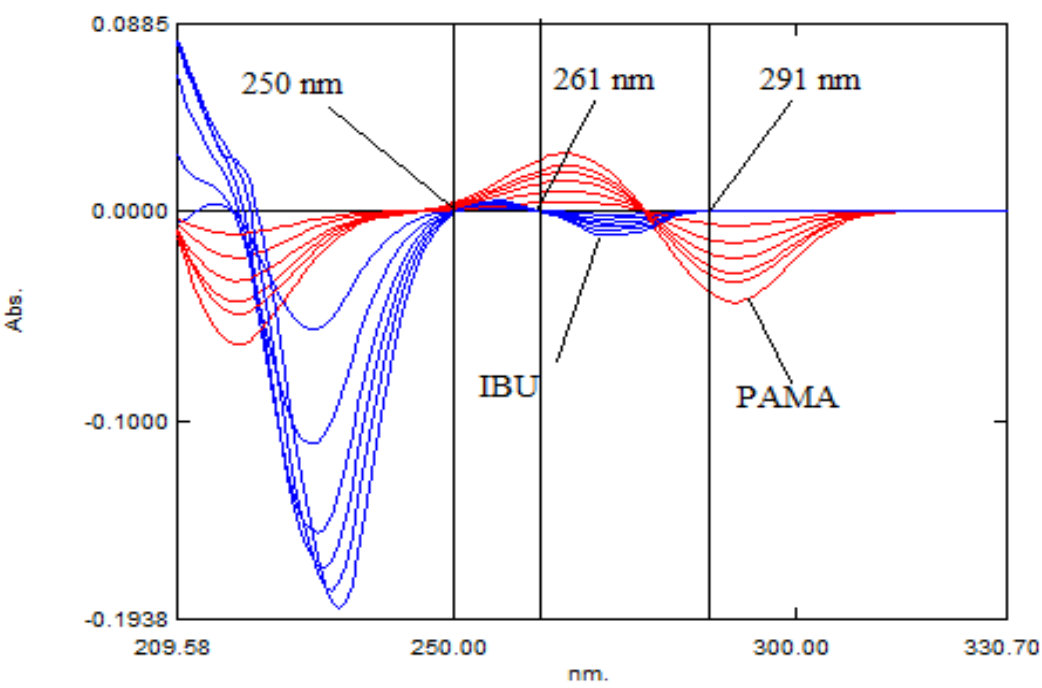

Fig. 3: Overlain $D^{1}$ spectra of IBU and PAMA

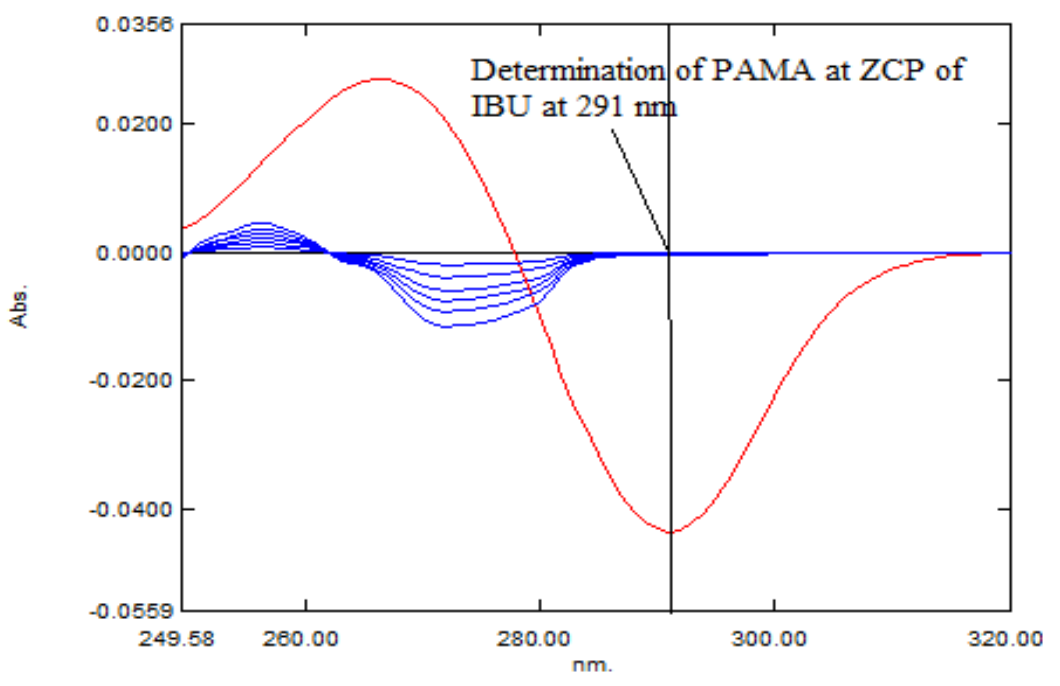

Fig. 4: Determination of PAMA at ZCP of IBU at $291 \mathrm{~nm}(12 \mu \mathrm{g} / \mathrm{ml})$ 


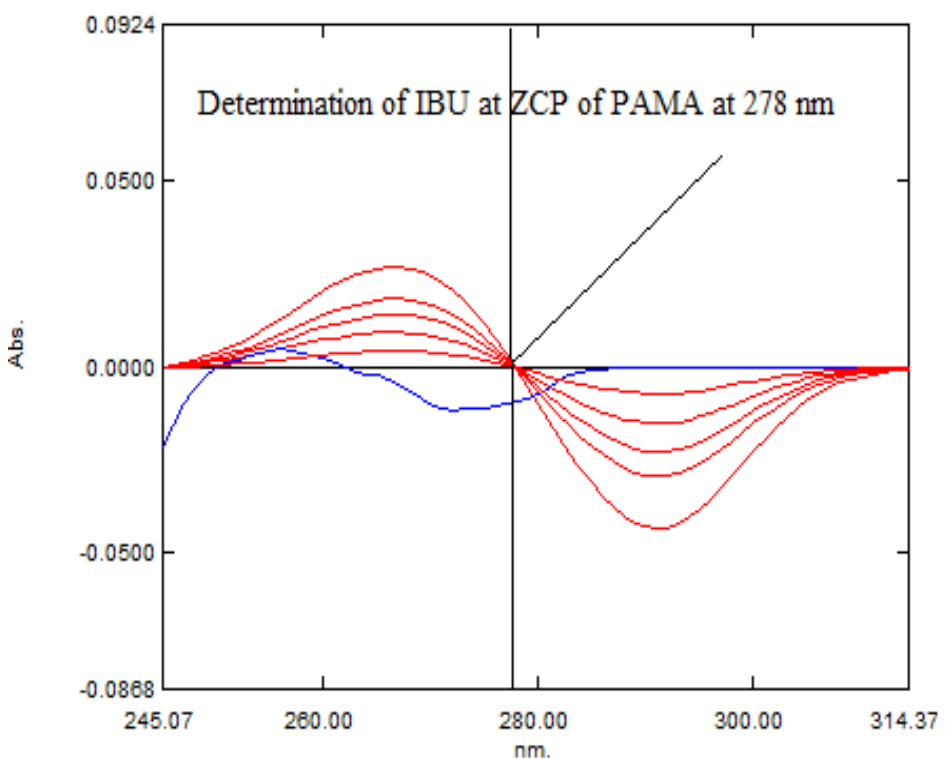

Fig. 5: Determination of IBU at ZCP of PAMA at $278 \mathrm{~nm}(120 \mu \mathrm{g} / \mathrm{ml})$

\section{Analytical method validation}

\section{Linearity and range}

When $\mathrm{D}^{1}$ Absorbance was plotted against concentration, nonlinearity was observed above $12 \mu \mathrm{g} / \mathrm{ml}$ for PAMA and above 120 $\mu \mathrm{g} / \mathrm{ml}$ for IBU, so final range for validation was selected at mixture containing 2-12 $\mu \mathrm{g} / \mathrm{ml}$ for PAMA and $20-120 \mu \mathrm{g} / \mathrm{ml}$ for IBU (fig. 6) When the calibration curve was plotted for given concentration range (fig. 7 and 8), value of linear regression coefficient was found to be 0.99898 for PAMA and 0.99876 for IBU. Regression equation was found to be $\mathrm{y}=0.00361 \mathrm{X}-0.00051$ for PAMA and $\mathrm{y}=0.00008$ $\mathrm{X}-0.00011$ for IBU. Linearity data for both drugs is shown in table 2 .

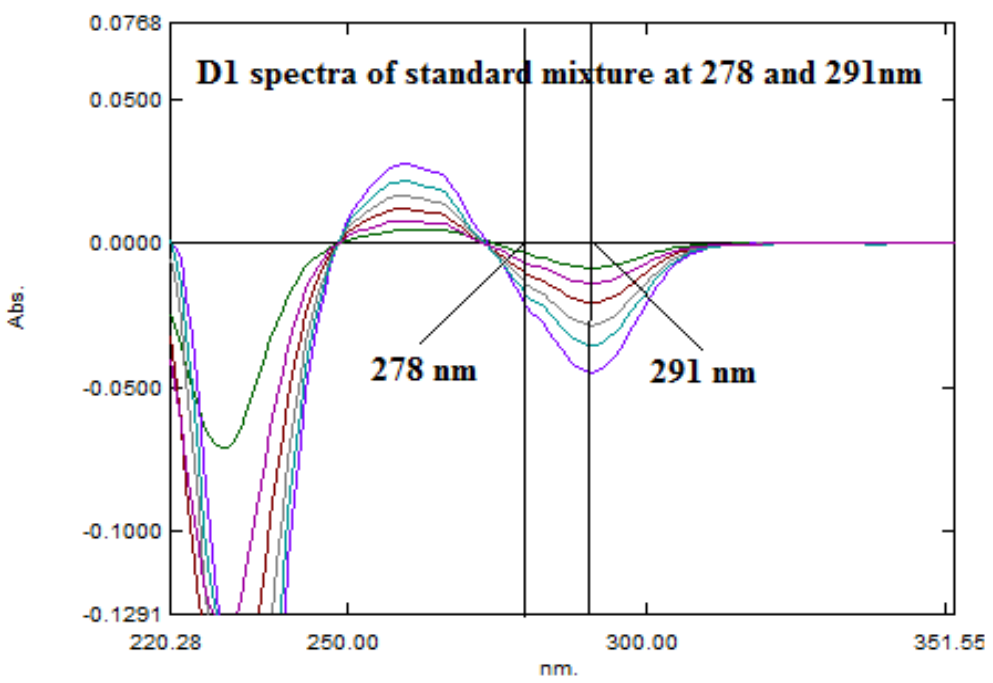

Fig. 6: $D^{1}$ Spectra of a standard mixture of IBU $(20-120 \mu \mathrm{g} / \mathrm{ml})$ and PAMA $(2-12 \mu \mathrm{g} / \mathrm{ml})$ for linearity stud

Table 2: Linearity data for PAMA and IBU

\begin{tabular}{|c|c|c|c|c|c|c|}
\hline \multirow[t]{2}{*}{ S. No. } & \multicolumn{3}{|l|}{ For PAMA } & \multicolumn{3}{|l|}{ For IBU } \\
\hline & Conc. $(\mu \mathrm{g} / \mathrm{ml})$ & mean \pm SD & RSD & Conc. $(\mu \mathrm{g} / \mathrm{ml})$ & mean \pm SD & RSD \\
\hline 1 & 2 & $-0.00716 \pm 0.00011$ & 1.592 & 20 & $-0.00159 \pm 0.000013$ & 0.815 \\
\hline 2 & 4 & $-0.01516 \pm 0.00011$ & 0.752 & 40 & $-0.00317 \pm 0.000042$ & 1.329 \\
\hline 3 & 6 & $-0.02276 \pm 0.00011$ & 0.500 & 60 & $-0.00478 \pm 0.000045$ & 0.947 \\
\hline 4 & 8 & $-0.02944 \pm 0.00011$ & 0.387 & 80 & $-0.00616 \pm 0.00011$ & 1.850 \\
\hline 5 & 10 & $-0.03654 \pm 0.00011$ & 0.312 & 100 & $-0.00756 \pm 0.00011$ & 1.508 \\
\hline 6 & 12 & $-0.04358 \pm 0.00008$ & 0.191 & 120 & $-0.00936 \pm 0.00011$ & 1.218 \\
\hline
\end{tabular}

$(n=5$ determinations $)$ 


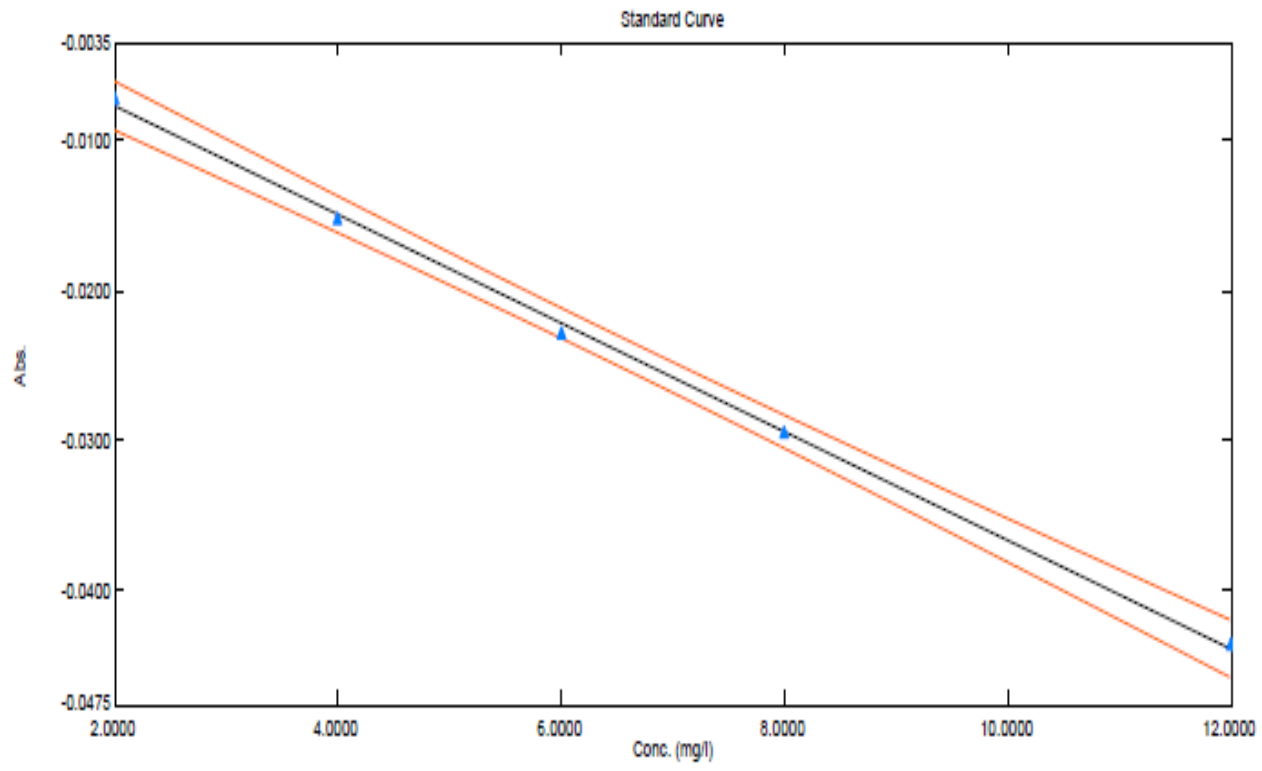

Fig. 7: Calibration curve of PAMA at 291 nm

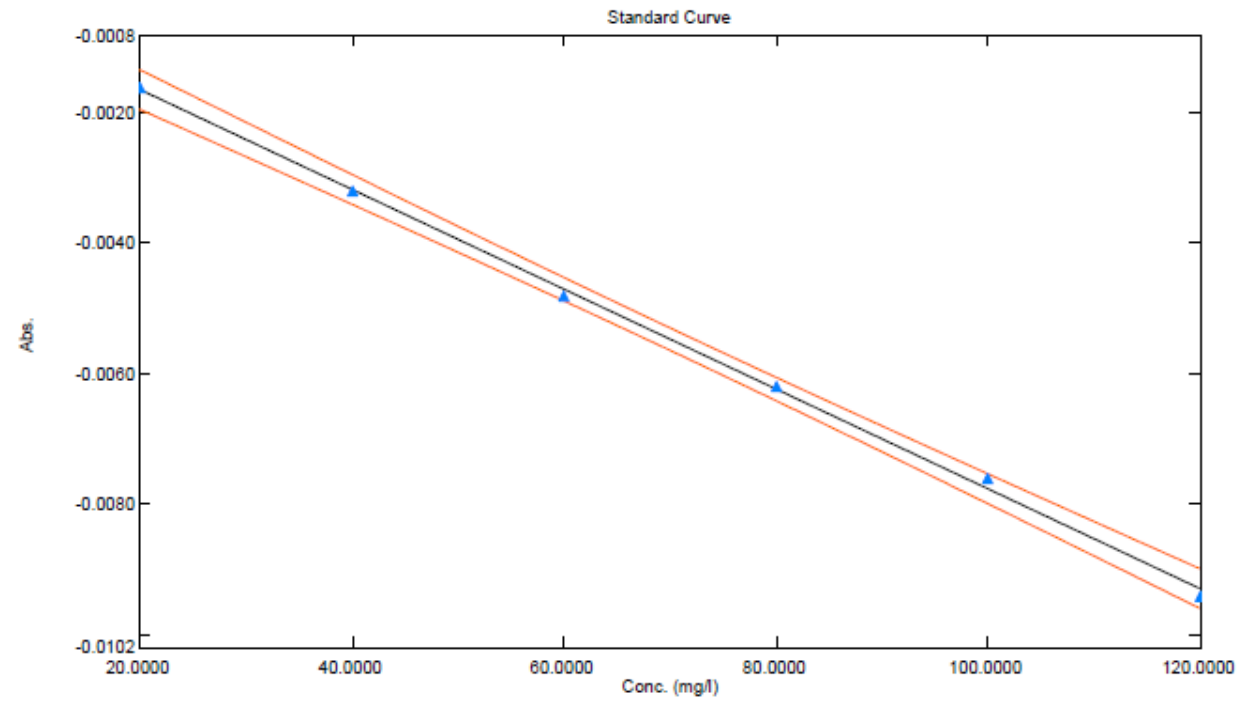

Fig. 8: Calibration curve of IBU at $278 \mathrm{~nm}$

\section{Repeatability}

When all mixture were analyzed at all concentration, calculated relative standard deviation at each level was found to be less than 2 so that method was found to be repeatable over the range of 2-12 $\mu \mathrm{g} / \mathrm{ml}$ for PAMA and $20-120 \mu \mathrm{g} / \mathrm{ml}$ for IBU. Repeatability data are shown in table 3 and 4 for PAMA and IBU, respectively.

\section{Method precision}

For determining interday and intraday precision, RSD was monitored at selected concentration level, which was found to be less than 2 so the method was found to be precise for estimation of PAMA and IBU. Data for intermediate precision are given in table 5 and 6 for PAMA and INU respectively.

Table 3: Repeatability data for PAMA at $291 \mathrm{~nm}$

\begin{tabular}{llllll}
\hline Conc. $(\boldsymbol{\mu g} / \mathbf{m l})$ & $\mathbf{2}$ & $\mathbf{4}$ & $\mathbf{6}$ & $\mathbf{8}$ & $\mathbf{1 2}$ \\
\hline & -0.0072 & -0.0152 & -0.0228 & -0.0294 & -0.0365 \\
D1 Absorbance & -0.0071 & -0.0153 & -0.0227 & -0.0295 & -0.0368 \\
& -0.007 & -0.015 & -0.0228 & -0.0296 & -0.0364 \\
& -0.0072 & -0.0151 & -0.0226 & -0.0293 & -0.0365 \\
Mean & -0.0073 & -0.0152 & -0.0229 & -0.0294 & -0.0367 \\
SD & -0.00716 & -0.01516 & -0.02276 & -0.02944 & -0.03654 \\
R. SD & 0.000114 & 0.000114 & 0.000114 & 0.000114 & 0.000114 \\
\hline
\end{tabular}

$(n=5$ determinations $)$ 
Table 4: Repeatability data for IBU at $278 \mathrm{~nm}$

\begin{tabular}{llllll}
\hline Conc. $(\boldsymbol{\mu g} / \mathbf{m l})$ & $\mathbf{2 0}$ & $\mathbf{4 0}$ & $\mathbf{6 0}$ & $\mathbf{8 0}$ & $\mathbf{1 0 0}$ \\
\hline & -0.00161 & -0.0032 & -0.0048 & -0.0062 & -0.0076 \\
D1 Absorbance & -0.00159 & -0.00319 & -0.0047 & -0.0061 & -0.0077 \\
& -0.00161 & -0.0031 & -0.0048 & -0.0063 & -0.0075 \\
& -0.00158 & -0.00318 & -0.00481 & -0.0062 & -0.0094 \\
Mean & -0.0016 & -0.0032 & -0.00479 & -0.006 & -0.0076 \\
SD & -0.00159 & -0.00317 & -0.00478 & -0.00616 & -0.00756 \\
R. SD & 0.00001 & 0.00004 & 0.00004 & 0.00011 & 0.00011 \\
\hline
\end{tabular}

( $n=5$ determinations $)$

Table 5: Intraday and interday precision for PAMA

\begin{tabular}{llll}
\hline Conc. $(\boldsymbol{\mu g} / \mathbf{m l})$ & Intraday $($ mean+SD) & RSD & Inter-day (mean+SD) \\
\hline 2 & $-0.007192+0.000013$ & 0.18 & $-0.007228+0.000019$ \\
8 & $-0.0294+0.00015$ & 0.53 & $-0.02942+0.00019$ \\
12 & $-0.04362+0.00025$ & 0.59 & $-0.0446+0.00035$ \\
\hline
\end{tabular}

( $\mathrm{n}=3$ determinations)

Table 6: Intraday and interday precision for IBU

\begin{tabular}{llll}
\hline Conc. $(\boldsymbol{\mu g} / \mathrm{ml})$ & Intraday (mean+SD) & RSD & Inter-day (mean+SD) \\
\hline 20 & $-0.00162+0.000019$ & 1.19 & $-0.001736+0.000021$ \\
80 & $-0.0062+0.000042$ & 0.67 & $-0.0066+0.000026$ \\
120 & $-0.00932+0.000113$ & 1.20 & $-0.00966+0.000036$ \\
\hline
\end{tabular}

( $\mathrm{n}=3$ determinations)

Table 7: Accuracy data of PAMA and IBU by derivative spectroscopy method

\begin{tabular}{|c|c|c|c|c|c|c|c|}
\hline \multirow[t]{2}{*}{ Level of spiking } & \multirow[t]{2}{*}{ Total placebo (mg) } & \multicolumn{2}{|c|}{ Amount of std. drug added $(\mu \mathrm{g} / \mathrm{ml})$} & \multicolumn{2}{|c|}{ Amount of drug recovered $(\mu \mathrm{g} / \mathrm{ml})$} & \multicolumn{2}{|c|}{ \% recovery } \\
\hline & & PAMA & IBU & PAMA & IBU & PAMA & IBU \\
\hline Unspiked & 104 & - & - & - & - & - & - \\
\hline $50 \%$ & 104 & 4 & 40 & $4.03+0.025$ & $40.2+0.32$ & $100.9+0.6$ & $100.6+0.6$ \\
\hline $100 \%$ & 104 & 8 & 80 & $8+0.03$ & $80.5+0.64$ & $99.9+0.3$ & $100.7+0.8$ \\
\hline $150 \%$ & 104 & 12 & 120 & $11.95+0.04$ & $120.4+0.65$ & $99.7+0.2$ & $100.3+0.5$ \\
\hline
\end{tabular}

( $\mathrm{n}=3$ determinations)

Table 8: Assay of the synthetic mixture by validated $1^{\text {st }}$ order derivative spectroscopic method

\begin{tabular}{|c|c|c|c|}
\hline Drug & Amount taken $(\mu \mathrm{g} / \mathrm{ml})$ & Amount recovered $(\mu \mathrm{g} / \mathrm{ml})$ & \% Assay \\
\hline PAMA & 8 & $7.99+0.6$ & $100.0+0.6$ \\
\hline IBU & 80 & $80.14+0.7$ & $100.1+0.7$ \\
\hline
\end{tabular}

( $\mathrm{n}=3$ determinations $)$

\section{Accuracy study}

Spiked placebo with standard solution at 50, 100 and 150\% level was analyzed for \% recovery, which was found within 98 to 102 , so the method was found to be accurate (table 7).

\section{Solvent stability}

As the $\lambda_{\max }$ was stable over a period of $24 \mathrm{~h}$, the solvent was found to be suitable and the drug was found to be stable.

\section{Assay}

When prepared synthetic mixture was analyzed by the developed and validated method, $\%$ assay was found to be $100.0+0.6$ for PAMA and for100.1+0.7 IBU (table 8).

\section{CONCLUSION}

The $1^{\text {st }}$ order derivative spectroscopic method was developed and validated as per ICH Q2 R1 guidelines and was successfully applied for determination of PAMA and IBU from its synthetic mixture. The present method was found to be economical in terms of cost and time. Commonly used excipient didn't interfered in the estimation of PAMA and IBU so the method was found to be specific. Method was also found to be repeatable and precise.

\section{ACKNOWLEDGMENT}

Authors are extremely grateful to OSAKA pharmaceuticals limited and Amoli organics for providing a gratis sample of IBU and PAMA. The authors are also grateful to Smt. S. M. Shah Pharmacy College for providing excellent research facilities and promoting research activities.

\section{AUTHORS CONTRIBUTIONS}

All authors have contributed equally for the successful execution of research and completion with beneficial outcomes.

\section{CONFLICT OF INTERESTS}

Declared none 


\section{REFERENCES}

1. Patil MV, Kolekar GB. Binding of drug pamabrom to Human hemoglobin: structural and thermodynamic characterization studies. Int J Sci Res 2014;3:3095-109.

2. Hesham S, Dalia M. Simultaneous determination of pamabrom and paracetamol in bulk powders and womankit tablets using spectrophotometric and chemometric-assisted spectrophotometric methods. Anal Chem Indian J 2013;13:6-16.

3. Doreen Tan SY, Sklar GE. Erythema multiforame secondary to dimenhydrinate in a patient with previous similar reactions to pamabrom. Annals Pharmacother 2014;48:425-8.

4. Alsaad AA, Alassadi ES, Hussein HH. The simultaneous determination of ibuprofen and paracetamol in pharmaceutical formulations by HPLC with UV detection. Asian J Pharm 2019;13:141.

5. Sharma H, Vishakha K, Kondreddy VK, Bhatta HP. Validated RPHPLC method for simultaneous estimation of paracetamol, pamabrom and dicyclomine hydrochloride in bulk and pharmaceutical dosage form. Int J Pharm Sci Res 2016;7:316-24.

6. Abdelaleem EA, Naguib IA, Hassan ES, Ali WN. Development and validation of three spectrophotometric methods for simultaneous determination of paracetamol and pamabrom in bulk and pharmaceutical formulation. Anal Chem Lett 2016;6:13-23.

7. Bashyal S. A review: ibuprofen and it's different analytical and manufacturing methods. Asian J Pharm Clin Res 2018;11:25-6.

8. Jun, Kang HS, Park JS. Simultaneous analysis of ibuprofen and pamabrom by HPLC. J Pharm Investig 2015;45:555-60.

9. Bambhrolia S, Rajput S. Simultaneous estimation of paracetamol and pamabrom in bulk drugs and in pharmaceutical formulation by spectrophotometry. Int J Chemtech Res 2013;5:1802-7.

10. Abdelaleem E. HPTLC and RP-HPLC methods for simultaneous determination of paracetamol and pamabrom in presence of their potential impurities. J Pharm Biomed Anal 2015;114:2227.

11. Atif S, Shahid A, Talib H, Rehan A, Gulam M, Muhhamad A, et al. Simultaneous determination of acetaminophen, pamabrom and pyrilamine maleate in pharmaceutical formulations using stability-indicating HPLC assay method. J Mexican Chem Soc 2015;59:93-8.

12. Shah D, Patel B, Bhavsar A. Stability indicating Rp-HPLC method for simultaneous estimation of paracetamol and pamabrom in bulk and combined pharmaceutical dosage form. World J Pharm Pharm Sci 2014;3:1009-20.

13. El-Houssini OM. Rp-Lc and TLC densitometric determination of paracetamol and pamabrom in the presence of hazardous impurity of paracetamol and application to pharmaceuticals. Anal Chem Insights 2013;8:73-81.
14. Shah U, Kavad M, Raval M. Development and validation of stability-indicating RP-HPLC method for estimation of pamabrom in tablets. Indian J Pharm Sci 2014;76:198-202.

15. Sharma H. Validated RP-HPLC method for simultaneous estimation of paracetamol, pamabrom and dicyclomine, hydrochloride in bulk and pharmaceutical dosage form. Int J Pharm Sci Res 2016;7:316-24.

16. Zhou LJ, Gu LH, Wang YJ, Liang JY. Determination of two constituents in compound acetaminophen and pamabrom tablets in human plasma by high-performance liquid chromatography. Chin J New Drugs Clin Remedies; 2007. p. 3.

17. Dhruvi S, Ankita B, Bhagirath P. Development and validation of reverse phase high performance liquid chromatographic method for simultaneous estimation of paracetamol and pamabrom in the combined dosage form. Res Rev J Pharm Pharm Sci 2014;3:16-23.

18. Harde MT, Winked SB, Chaudhari PD. Development and validation of RP-HPLC method for estimation of pamabrom in bulk and marketed formulation. J Pharm Res 2014;8:1515-9.

19. Lucio Maldonado S, Cruz Salins MA. Bioanalytical method for pamabrom and its application to a pharmacokinetic study. J Bioequivalence Studies 2017;3:101.

20. Reddy YR, Kumar KK. RP-UPLC method development and validation for the simultaneous estimation of ibuprofen and famotidine in the pharmaceutical dosage form. Pharm Methods 2012;3:57-61.

21. Battu PR, Reddy MS. RP-HPLC method for simultaneous estimation of paracetamol and ibuprofen in tablets. Asian J Res Chem 2009;2:70-2.

22. Gnana Raja M, Geetha G, Sangaranarayanan A. Simultaneous, stability-indicating method development and validation for related compounds of ibuprofen and paracetamol tablets by RP-HPLC method. J Chromat Separation Techniq 2012;3:155.

23. Sanchaniya PM, Mehta FA, Uchadadiya NB. Development and validation of an RP-HPLC method for estimation of chlorpheniramine maleate, ibuprofen, and phenylephrine hydrochloride in the combined pharmaceutical dosage form. Chromatogr Res Int 2013:1-6. http://dx.doi.org/ 10.1155/ $2013 / 424865$.

24. Volonte MG, Valora PD. Stability of ibuprofen in injection solutions. Am J Health Syst Pharm 2005;62:630-3.

25. Kesur BR, Salunkhe VR, Magdum CS. Development and validation of UV spectrophotometric method for simultaneous estimation of ibuprofen and famotidine in bulk and formulated tablet dosage form. Int J Pharm Pharm Sci 2012;4:271-4.

26. Bachri M, Tuty RP, Edward R. Quantitative analysis of acetaminophen and Ibuprofen mixture in tablet utilizing centered average on spectrum ratio by spectrophotometric technique. Asian J Pharm Clin Res 2018;11:344-9. 